\title{
The Tommot pluton: a Middle Paleozoic rift-related alkaline gabbro and syenite complex, Yakutia, northeast Russia
}

\author{
V. A. Trunilina ${ }^{1}$, P. W. Layer ${ }^{2}$, L. M. Parfenov ${ }^{*}, \dagger$, A. I. Zaitsev ${ }^{1}$, and Y. S. Orlov ${ }^{3}$ \\ ${ }^{1}$ Yakutian Diamond and Precious Metal Geology Institute, Siberian Branch, Russian Academy of Sciences, 39 Lenin \\ Prospect, 677891, Yakutsk, Russia \\ ${ }^{2}$ Geophysical Institute, University of Alaska Fairbanks, Fairbanks, AK 99775, USA \\ ${ }^{3}$ Yakutian State Geological Expedition, 13 Kirov Street, 677891, Yakutsk, Russia \\ * formaly at: Yakutian Diamond and Precious Metal Geology Institute, Siberian Branch, Russian Academy of Sciences, 39 \\ Lenin Prospect, 677891, Yakutsk, Russia \\ ${ }^{\dagger}$ deceased
}

\begin{abstract}
The Tommot pluton is located within the continental Omulevka terrane of the inner zone of the VerkhoyanskKolyma Mesozoic orogen. It is a small complex $\left(\sim 12 \mathrm{~km}^{2}\right)$ composed of alkaline-ultramafic rocks, alkaline and subalkaline gabbroids, and alkaline and quartz syenites. The pluton is unique both in the composition and age of its constituent rocks. Mineralogical-petrographical and geochemical studies of the rocks indicate that the alkaline rocks resulted from the melting of depleted mantle horizons. K-Ar, $\mathrm{Rb}-\mathrm{Sr}$, and ${ }^{40} \mathrm{Ar} /{ }^{39} \mathrm{Ar}$ age determinations confirm a Paleozoic age of the rocks. Formation of the alkaline rocks is related to Middle Paleozoic rifting which occurred as two discrete events: a Late Devonian event, which affected the marginal part of the Siberian continent, and a Late Carboniferous event that reflects internal deformation of the Omulevka terrane or late-stage extension. A spatially associated alkali granite, the Somnitel'nyy pluton, is Late Jurassic-Early Cretaceous in age and is synchronous with accretion of the KolymaOmolon Superterrane to Siberia in the Mesozoic.
\end{abstract}

\section{Introduction}

Alkaline igneous rocks and bimodal volcanism are generally associated with rift setting and imply some interaction with mantle-derived magmatism. Identification and dating of these rocks provides constraints on the tectonics of a region, especially as it relates to continental rifting and extension. Alkaline rocks are relatively rare in northeastern Russia, perhaps due to fragmentation and accretion of a myriad of terranes in the region. In this paper we report on the geochem-

Correspondence to: P. W. Layer

(player@gi.alaska.edu) istry and geochronology of one of the best preserved alkaline complexes, the Tommot pluton, which occupies a unique place in the "Verkhoyansk-Kolyma Mesozoides" (Parfenov, 1991) and provides insights into the evolution of the region.

The Middle Paleozoic Tommot pluton $\left(12 \mathrm{~km}^{2}\right.$ in area) is located in the north of the inner zone of the VerkhoyanskKolyma Mesozoides which cover vast areas in northeast Asia east of the Siberian platform. It is made of alkaline rocks of various compositions (from ultramafic foidolites to leucocratic alkali-syenites) with gabbroids predominating among them. Adjacent to the southern contact of the Tommot pluton there is a small pluton (Somnitel'nyy) of about $1 \mathrm{~km}^{2}$ in area that is made of alkaline and subalkaline granites with the rare-earth mineralization intruding the gabbroids. Granites of similar composition crop out at the northern contact of the Tommot pluton as well.

Both plutons were studied in detail in the 50s and 60s (Nekrasov, 1962; Proshchenko and Nenashev, 1969). The Tommot pluton was regarded as a polyphase ring intrusion of gabbro-syenite composition which is reflected in the traditional rock names used to describe it: pyroxenite, gabbro, diorite, etc. In this paper, we establish the presence of rare nepheline, melilite, adularia, and orthoclase grains in the ultramafic and mafic rocks. The results of chemical analyses showed that rocks of the normal series occur in the Tommot pluton only rarely. The rocks are mainly nepheline or nepheline-leucite normative, i.e. they belong to the alkaline series and this fact predetermined the nomenclature used in this paper. The problem of the age of magmatic rocks rose as early as the 60s as a result of K-Ar dating. Ultramafic rocks were dated as Devonian, syenites as Early Triassic, and granites as Early-Middle Jurassic (Proshchenko and Nenashev, 1969) and the age of the Tommot pluton was shown as Late Carboniferous on geological maps (Dorofeev, 1967).

Published by Copernicus Publications on behalf of the European Geosciences Union. 
The Tommot pluton is, both in composition and age, unique in the inner areas of the Verkhoyansk-Kolyma Mesozoides where extensive belts of Late Mesozoic collisional granites are more widespread. Only two other similar formations have been found in eastern Russia: one in the extreme south of the region in the marginal part of the Verkhoyansk miogeoclinal foldbelt and one in the north of the eastern margin of the Siberian platform (Fig. 1). In the southern Verkhoyansk foldbelt a chain of small plutons (Gornoozerskiy, Povorotnyy, etc.) of ultramafic alkaline rocks is traceable. They are composed of pyroxenites, ijolites, nepheline syenites, and carbonatites. In the northern Siberian platform, $200 \mathrm{~km}$ away from the Verkhoyansk foldbelt boundary, the Tomtor pluton is composed of foidolites, alkaline gabbroids, nepheline syenites, and carbonatites. These formations are accompanied by the rare-earth mineralization, with the Tomtor field ranking fifth among the largest deposits of the world. $\mathrm{K}-\mathrm{Ar}$ and $\mathrm{Rb}-\mathrm{Sr}$ dating of the rocks of the Tomtor and Gornoozerskiy plutons yielded wide age ranges of 244-800 Ma and 170-487 Ma, respectively, with the predominance of Middle Paleozoic dates (Entin et al., 1990, 1991).

The aim of the authors was to study comprehensively various rock types of the Tommot and Somnitel'nyy plutons and to establish their age and genetic relations. For this purpose we carried out a detailed petrographic study of the rocks and a large volume of analytical investigations: silicate and spectral quantitative analyses of the rocks; microprobe analyses of the rock-forming and accessory minerals on a Camebaxmicro X-ray microprobe. $\mathrm{K}$-Ar and $\mathrm{Rb}$-Sr age determinations of the rocks and minerals were performed at the Yakutian Institute of Geological Sciences SO RAN; ${ }^{40} \mathrm{Ar} /{ }^{39} \mathrm{Ar}$ age determinations were done at the Geophysical Institute of the University of Alaska Fairbanks. Plasma-spectral determinations of rare-earth elements were carried out at the Siberian Research Institute of Geology and Mineral Deposits (Novosibirsk).

\section{Tectonic setting}

The location of the Tommot pluton and other similar formations within the Verkhoyansk-Kolyma Mesozoides is shown on the tectonic map (Fig. 1) and on the map of Middle Paleozoic rift-related structures compiled on the basis of drilling and geophysical data. The description of these structures was discussed in Parfenov (1991, 1994). The Tommot pluton is located in the Omulevka terrane, which is composed mainly of shallow-water carbonate deposits of Ordovician, Silurian, and Devonian age. The magmatic rocks of the Tommot pluton intrude presumably Early Paleozoic schists and para- and orthogneisses of granite composition, which are in fault contact with the Paleozoic, carbonate rocks (Fig. 2).

The available paleomagnetic data suggest that the Omulevka terrane is a fragment of the Early Paleozoic carbonate platform of Siberia. It was detached from Siberia in the Early Carboniferous and displaced to the south for a distance of about $10-15^{\circ}$ (in latitude) and then reattached in the Early Cretaceous (Neustroev et al., 1993; Parfenov, 1991, 1994; Stone, 2004). Because of this fragmentation and later accretion, it is likely that rift-related rocks were not well preserved, and the Tommot pluton represents one small remnant of a much larger igneous belt.

\section{Petrography and mineralogy of the Tommot pluton rocks}

\subsection{Petrography}

The Tommot pluton is composed of three rock types: alkaline-ultramafic rocks, alkaline and subalkaline gabbros, and alkaline syenites (Fig. 2). The host rocks include para-amphibolite, granite-gneiss, feldspar-quartz-amphibole, feldspar-quartz, biotite-quartz-feldspar and quartz-chloriteactinolite crystalline schists, as well as marble and metamorphosed limestone. The host schists dip beneath the Tommot pluton along its periphery.

Alkaline-ultramafic rocks make up gently dipping sheetlike bodies up to $500 \mathrm{~m}$ thick striking southwest-northeast for about $2.5 \mathrm{~km}$ parallel to the general outline of the Tommot pluton. On the margins of the bodies, numerous xenoliths and xenoblocks of crystalline schists are observed. The contacts are intrusive, and the ultramafic rocks are fine-grained near the contact. The ultramafic outcrops are blocky in nature due to intense post-intrusive faulting mainly of strikeslip fault kinematics. The least altered feldspar-free varieties are made up of olivine, ortho- and clinopyroxene, amphibole, magnetite, spinel, and apatite. Up section, the feldspar-free jacupirangites are replaced by feldspar ones and melteigites and further up by melanocratic gabbroids. The sequence of crystallization of the rock-forming minerals is, in general, close to the Bowen series. Single melilite, nepheline, and orthoclase grains occur intersticially. The vein facies is represented by rare anorthosite (plagioclasite) bodies.

Alkaline and subalkaline gabbros (subalkaline and feldspathoid essexite, theralite and shonkinite) and rare pyroxenite form a large lenticular body (about $12 \mathrm{~km}^{2}$ ). The presumed maximum thickness is up to $1 \mathrm{~km}$. The gabbroids intrude the ultramafic bodies and contain numerous broken xenoliths and large blocks of the ultramafics. In turn, the gabbroids are cut by plagioclasite, hornblendite, and syenite veins. At the contacts with the latter they are intensely broken down, schistose, crushed and, together with the host rocks, cemented by syenite material. The gabbroids are dominated by amphibole-pyroxene bearing phases, with olivine-pyroxene and biotitized phases being subordinate. Melanocratic varieties contain sporadic melilite and nepheline, while leucocratic ones commonly include $\mathrm{K}$ feldspar. Primary macro- and micro-laminations are distinct. The former is expressed by the predominance of melanoand mesocratic (including ultramafics) rocks in the lower 

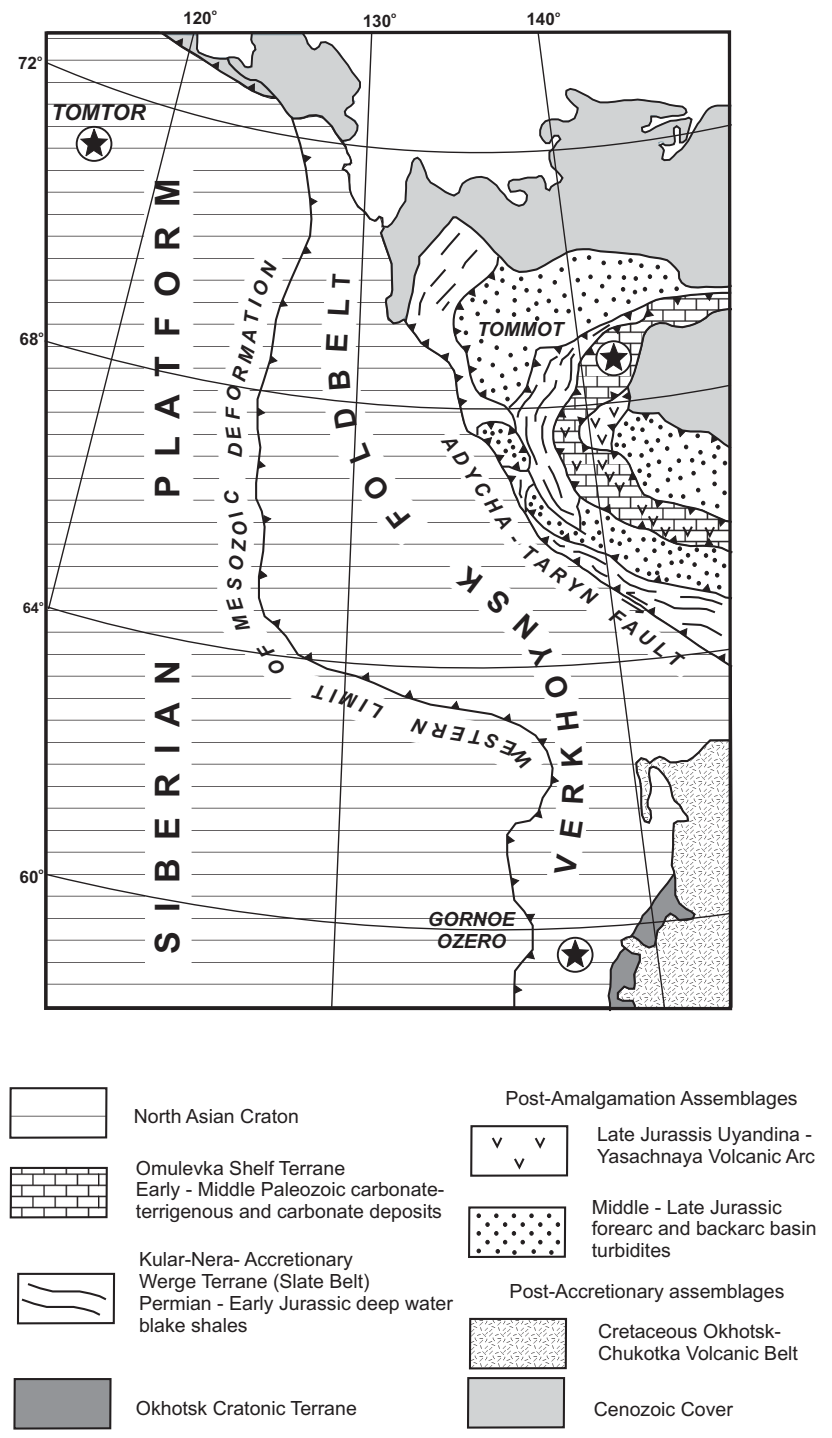

Fig. 1. Generalized geologic map of east-central Russia showing the location of the Tommot pluton and other Paleozoic alkaline plutons.

horizons, and meso- and leucocratic rocks in the upper horizons. Microlaminations are most clearly seen in the central part of the body and are manifested in the form of banded rocks (melano- and leucocratic separations) with the bands ranging in thickness from a few to tens of centimeters. Intense post-intrusive faulting and deformation caused rotation of the orientation of the primary banding in various blocks.

The ultramafic and mafic units are accompanied by lensand vein-like plagioclasite and hornblendite bodies. The former crystallized from residual melts at different horizons and compositionally correspond to plagioclase of the gabbroids from these horizons (from bytownite to oligoclase). The latter developed both metasomatically (pyroxene is replaced by amphibole) and after pegmatite (coarse-grained monomineral and orthoclase-bearing hornblendites).

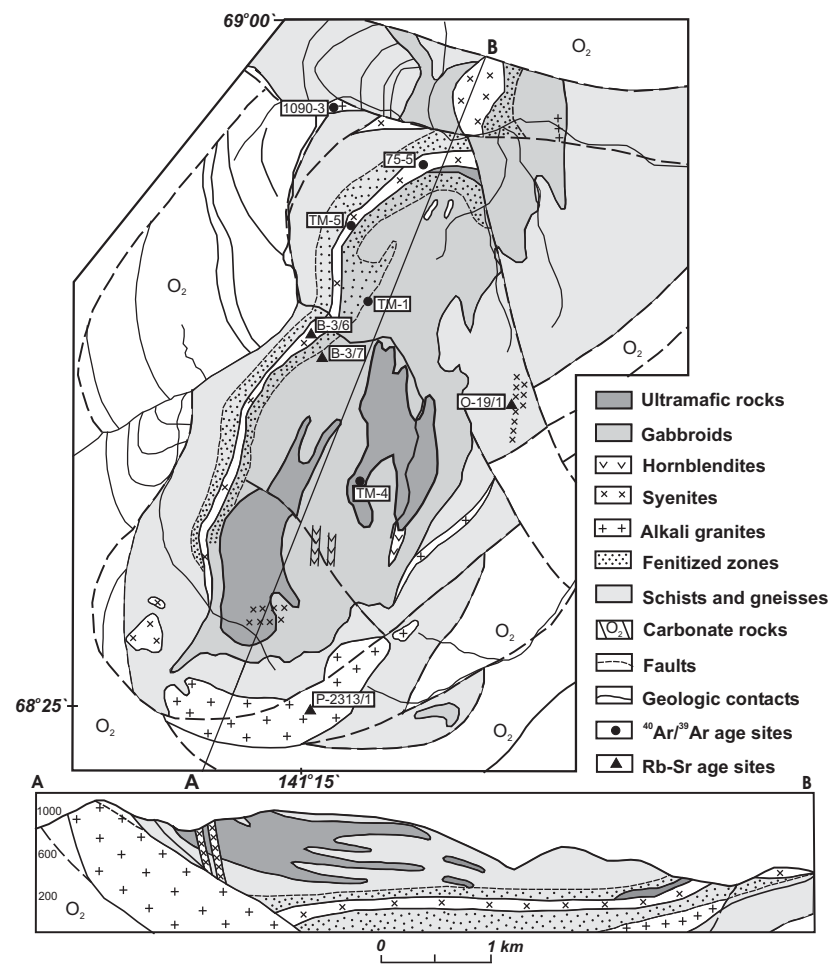

Fig. 2. Geological map and cross section of the Tommot pluton showing the locations of sites dated by ${ }^{40} \mathrm{Ar} /{ }^{39} \mathrm{Ar}$ and $\mathrm{Rb}-\mathrm{Sr}$ geochronology.

Alkali-syenites (toensbergite, pulaskite) make up sheetlike bodies from 30 to $100 \mathrm{~m}$ thick at the western contact of the gabbroid pluton that dips to the east at the angles of $40^{\circ}$ to $60^{\circ}$. At the syenite contacts, schists, gneisses, and gabbroids are intensely feldspathized to form metasomatic $\mathrm{K}-\mathrm{Na}$ feldspars and alkali-amphiboles, while the syenites are intensely broken down. Blocks of the host rocks squeezed between the gabbroids and syenites are ground down to mylonites. The main rock-forming minerals are strongly albitized K-Na feldspar (largely mesoperthite), aegirine, and amphibole. Olivine and clinopyroxene relics are found. Significant (tenths of a percent in total) admixtures of apatite, sphene, and rare-earth elements are common.

\subsection{Mineralogy}

Olivine is represented in the ultramafics by chrysolite, in the mafics by chrysolite and hortonolite, and in the syenites by hortonolite. The iron content increases from 21 to $53 \%$ in the sequence. $\mathrm{Ca}$ is constantly present in olivine of the ultramafics as an admixture although it is more typical of the olivine from layered intrusions of stable areas. Besides $\mathrm{Ca}$, olivine from the gabbroids contains alkalis $(0.2-0.4 \%)$ and alumina (up to $0.4 \%$ ), which is typical of a high-alkali magmatic series. The crystallization temperature is 1080 to $1185^{\circ} \mathrm{C}$, which is markedly lower than that of the dry melt. 
Based on their chemical composition, the rocks with the maximum olivine content belong to the normal series. They also contain small amounts (often relics) of orthopyroxenebronzite and low-ferruginous (23-32\%) hypersthene comparable in the alumina/iron ratio to orthopyroxenes from layered intrusions of the continental ultramafics of normal alkalinity. The crystallization temperature $\left(1100^{\circ} \mathrm{C}\right)$ is close to that of olivine. Its low $\mathrm{Al}_{2} \mathrm{O}_{3}$ content (3\%) indicates the depletion of the parental substratum in easily fusible components and corresponds to its formation pressure of about $10 \mathrm{kbar}$ (using the geobarometer of Perchuk, 1970, 1977).

Pyroxenes of the ultramafic and mafic rocks are predominatly clinopyroxene (magnesian diopside and high-Ca augite). A crystallization temperature for clinopyroxene $\left(980^{\circ}-1040^{\circ} \mathrm{C}\right)$ is somewhat lower than that of the orthopyroxene, which it displaces. The prevalence of IV Al over VI Al indicates shallower depths of its crystallization (Perchuk, 1970, 1977). This is also supported by a substantial predominance of the mineral chermakite $(3-32 \%$ in ultramafics and mafics, $30-50 \%$ in syenites) over jadeite (0-7\%) (Andreeva et al., 1984). Based on its oxide ratio (Fig. 3), clinopyroxene is, in general, comparable to that from the alkaline series with some points (measurements taken mainly from cores and the rocks of normal alkalinity) falling into the field of pyroxenes of ultramafic-mafic rocks from layered intrusions of the normal series. Aegirine is more typical of syenites.

Amphibole first appeared as an overgrowth of pyroxene and then completely replaced it. It formed almost synchronously with plagioclase. Amphibole occurs in two generations. The first is represented by low-ferruginous (25$30 \%$ ) hornblende of the pargasite series, with IV Al prevailing over $\mathrm{VI} \mathrm{Al}$ (shallow depths of crystallization). It is comparable to amphibole from the derivatives of basaltoid magmas of normal alkalinity. As shown experimentally (Andreeva et al., 1984) the existence temperature of the pargasite hornblende is $840^{\circ}$ to $1025^{\circ} \mathrm{C}$ and the transition of the waterfree phase (diopside) into it occurs at a temperature of $955^{\circ} \mathrm{C}$, general pressure of $1-4 \mathrm{kbar}$, and the water vapor pressure of no less than $1 \mathrm{kbar}$. The second generation clearly substitutes for the first one and is represented by hastingsite (with the iron content ranging from 30 to $60 \%$ ) in the ultramafics and mafics, and hastingsite and fluor-thoramite in the syenites. It is characterized by remarkably low silica content (nephelinenormative composition). In its $\mathrm{Ca}$ :Al ratio (Fig. 4) it corresponds to amphiboles from the derivatives of K-Na alkalineultramafic and alkaline-mafic series. Thus, compositional duality of the minerals of ultramafics and mafics from the Tommot pluton easily seen from the pyroxenes can also be traced from the amphiboles.

Magmatic biotite was found only in alkali-syenites where it crystallized at a low temperature of $550^{\circ}-650^{\circ} \mathrm{C}$ (iron content $81-83 \%)$ and low oxygen $\left(-\log f \mathrm{O}_{2}=17.5-18\right)$ and water $\left(\log f \mathrm{H}_{2} \mathrm{O}^{-}=1.45\right)$ fugacities (Troshin et al., 1981; Wones and Eugster, 1965).

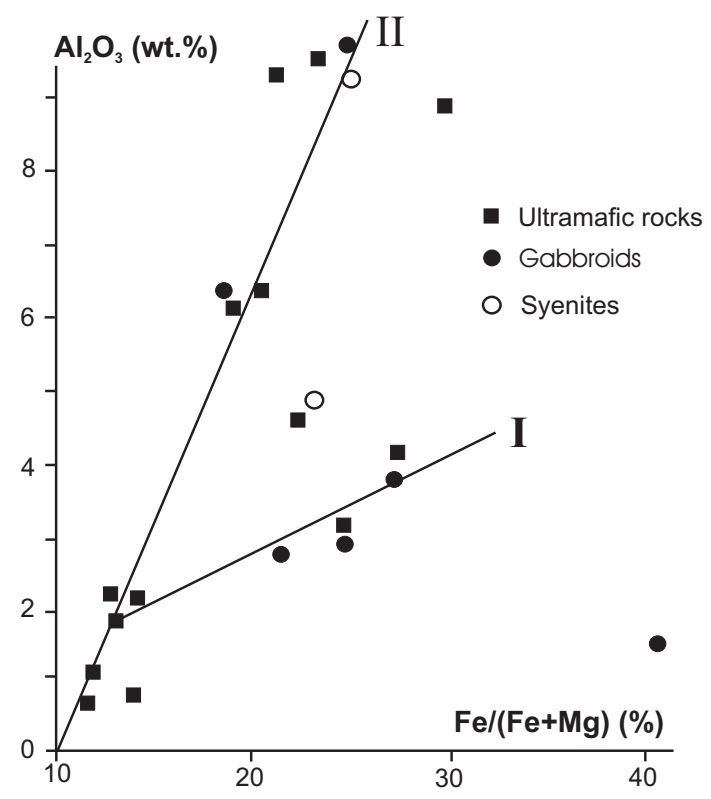

Fig. 3. Composition of clinopyroxenes from the rocks of the Tommot pluton. I - trend for clinopyroxenes from stratified mafic intrusions of normal alkalinity, II - trend for clinopyroxenes from alkaline rocks (Laz'ko, 1988).

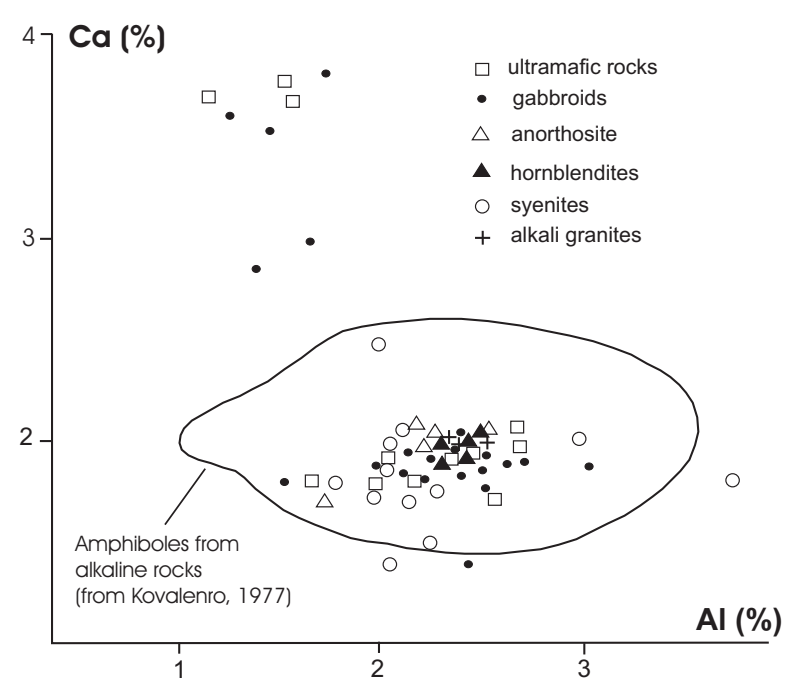

Fig. 4. Composition of amphiboles from the magmatic rocks of the Tommot and Somnitel'nyy plutons. Solid line denotes the range of compositions of amphiboles from alkaline rocks from Kovalenko (1977).

Plagioclase contains $97-75 \%$ An in ultramafic rocks and $82-52 \%$ An in mafic ones. It is anomalously rich in the orthoclase component: up to $10 \%$ in ultramafic rocks and up to $20 \%$ in mafic ones. Thin sections of some samples show intergrowths of late magmatic plagioclase with 4755\% An and K-Na feldspar of Ab 37-57 Ort 42-57 An 57 composition, which indicates crystallization temperatures 
of $850^{\circ}-950^{\circ} \mathrm{C}$. The alkali-syenites contain relics of K-Na feldspar of similar composition: Ab 42-61 Ort 22-54 An 417. Their plagioclase has the composition of oligoclasealbite and oligoclase (10-32\% An) with orthoclase up to 9.5\% and crystallization temperatures up to $1000^{\circ} \mathrm{C}$ (according to the geothermometer of Brown and Parsons, 1985).

Magnetite is a rock-forming mineral in ultramafic and mafic rocks (average $9.4 \%$ in the former and $4.1 \%$ in the latter). But it is only in a few gabbroids that high-Ti magnetite (up to $10 \% \mathrm{TiO}_{2}$ and $5 \% \mathrm{Al}_{2} \mathrm{O}_{3}$ with a significant admixture of $\mathrm{Mg}$ and $\mathrm{Na}$ ) typical of the alkaline series was found.

Apatite is represented by F-OH-apatite with a high $\mathrm{Cl}$ content (up to $0.8 \%$ ) and a $\mathrm{Cl} / \mathrm{Na}$ ratio of 3 to 8 , which makes it comparable to the high-temperature apatite derived from deep magmas (Bushlyakov and Kholodnov, 1986). Apatite from the syenites differs from that of the ultramafics and mafics only in a higher total of rare earth elements (averaging $0.48 \%$ ). Thus, characteristics of the rock-forming minerals from the ultramafic-syenite rocks of the Tommot pluton reflect high alkalinity of the melt.

\section{Petrography and mineralogy of the Somnitel'nyy pluton}

The main facies of the Somnitel'nyy pluton is represented by massive medium-grained alkaline and subalkaline granites grading at about $100 \mathrm{~m}$ from the contact into heterogeneous fine- to medium-grained granites and further on into finegrained porphyritic ones. At the contacts, pegmatoid granites are found locally. The contact zone is schistose and shows a eutaxitic structure with alternating melano- and leucocratic bands. The host rocks are intensely feldspathized. The contact zone (up to $30-50 \mathrm{~m}$ thick) is pierced with steeply dipping quartz-albite and quartz veins elongated parallel to the contact The granites are made of quartz, plagioclase, Kfeldspar, aegirine, amphibole, and biotite with a small admixture of muscovite, ore minerals, sphene, zircon, apatite, fluorite, and rare-earth minerals (tenths of a percent).

$\mathrm{K}$-feldspar, as in the syenites, is represented, mainly, by mesoperthite, while plagioclase by albite and oligoclase (1$20 \% \mathrm{An}$ ). The main dark-colored mineral is aegirine amphibole of the arfvedsonite series and is represented by lowferruginous $(38-42 \%)$ fluor-thoramite and eckermanite that crystallized at shallow depths. Biotite is late- and postmagmatic. It differs from biotite in the alkali-syenites in that it contains higher $\mathrm{F}, \mathrm{Ca}$, and $\mathrm{Na}$ and low iron content. The amount of $\mathrm{Cl}$ is moderate $(0.3 \%)$. Biotite crystallized at a temperature of $780^{\circ} \mathrm{C}$ under moderate oxygen $\left(-\log f \mathrm{O}_{2}=15\right)$ and water $\left(\log f \mathrm{H}_{2} \mathrm{O}=2.6\right)$ fugacities (Troshin et al., 1981; Wones and Eugster, 1965). Most common of the accessory minerals are zircon with high $\mathrm{U}$ and $\mathrm{Th}$ contents, columbite-tantalite, and rare-earth minerals. They are most abundant near the contact where both granites and host rocks are enriched in acicular apatite (total REE up to $1 \%$ ), fine-grained fluorite, and ore minerals, and contain large nests and streaky segregations of rare-earth minerals. Apatite with moderate $\mathrm{F}(2.1-2.4 \%)$ and low $\mathrm{Cl}(0.2 \%)$ contents is typical of the alkali-granites.

\section{Petrologic discussion}

Petrochemical characteristics of the Tommot pluton correspond to those of typical alkaline series rocks (Table 1). On petrochemical diagrams (Figs. 5-7) the composition points of all phases of the pluton, from ultramafics to syenites, form a single trend in the field of the derivatives of alkaline-mafic magmas of the alkali-basalt and basanite petrochemical series. Alumina and iron contents, total alkalis, and the differentiation index of the rocks increase in a systematic fashion with the increasing silicity, and the composition fields of the rocks of successive magmatic formations partially overlap each other on the diagrams. The differentiation trend is, in general, close to the normal evolution of alkali-basaltoid magmas. This, together with similarities of the rock-forming and accessory minerals, seems to indicate that ultramafics, mafics, and syenites of the Tommot pluton are derivatives of the three successive phases in the emplacement of a common evolving melt or genetically related melts, or, at least are derived under similar conditions.

Rocks of the normal series (pyroxenites, schriesheimites, wherlites, olivine-gabbros) occur sporadically among the ultramafics and mafics. Petrological calculations of P-Tconditions of crystallization indicate an upper mantle origin of the melts that typify normal rocks. Features of the rockforming and accessory minerals combining those of the minerals of normal and alkaline basites might be due to their crystallization from the evolving upper-mantle melts that were enriched in lithophile elements and alkalis in the course of their interaction with fluids and/or melts from deeper undepleted mantle horizons. One can assume that the interaction took place as early as the middle magmatic stage of ultramafics crystallization and strengthened with time, i.e., evolution of the original normal mafic magma was accompanied by its alkalization at depth.

Analysis of geochemical peculiarities of the magmatic rocks leads to a similar conclusion. The average contents of rare and rare-earth elements in the rocks of the complex (Table 1), the prevalence of light lanthanoids over heavy ones, and their $(\mathrm{Y}+\mathrm{Nb}) / \mathrm{Zr}$ ratios are comparable to those of the alkaline series rocks of intraplate magmatism showing similar silica content (Fig. 8). Along with this, there are wide ranges in the contents of these elements. In some of the samples the variations are almost identical (especially for the iron group elements) to those in continental tholeiites of the normal series.

The interpretation of composition points of alkali-granites from the Somnitel'nyy pluton on petrochemical diagrams is less certain. On some of the classification diagrams (Figs. 5 
Table 1. Average compositions of magmatic rocks of the Tommot and Somnitel'nyy plutons.

\begin{tabular}{|c|c|c|c|c|}
\hline $\mathrm{n}$ & $\begin{array}{l}\text { Ultra- } \\
\text { mafics } \\
21\end{array}$ & 49 & 41 & $\begin{array}{l}\text { Alkali- } \\
\text { granites } \\
26\end{array}$ \\
\hline \multicolumn{5}{|c|}{ Oxides, wt \% } \\
\hline $\mathrm{SiO}_{2}$ & 38.16 & 43.13 & 60.35 & 73.05 \\
\hline $\mathrm{TiO}_{2}$ & 3.92 & 3.23 & 0.69 & 0.34 \\
\hline $\mathrm{Al}_{2} \mathrm{O}_{3}$ & 15.43 & 17.19 & 18.68 & 10.63 \\
\hline $\mathrm{Fe}_{2} \mathrm{O}_{3}$ & 6.90 & 4.91 & 1.70 & 3.83 \\
\hline $\mathrm{FeO}$ & 8.45 & 7.85 & 2.46 & 1.43 \\
\hline $\mathrm{MnO}$ & 0.23 & 0.26 & 0.16 & 0.13 \\
\hline $\mathrm{MgO}$ & 8.09 & 5.31 & 0.49 & 0.24 \\
\hline $\mathrm{CaO}$ & 13.61 & 10.45 & 1.91 & 0.64 \\
\hline $\mathrm{Na}_{2} \mathrm{O}$ & 2.18 & 3.37 & 6.92 & 4.49 \\
\hline $\mathrm{K}_{2} \mathrm{O}$ & 0.80 & 1.40 & 4.60 & 4.35 \\
\hline $\mathrm{P}_{2} \mathrm{O}_{5}$ & 0.65 & 0.93 & 0.14 & 0.03 \\
\hline $\mathrm{CO}_{2}$ & 0.82 & 0.76 & 0.56 & 0.23 \\
\hline $\mathrm{H} 2 \mathrm{O}^{-}$ & 0.13 & 0.09 & 0.07 & 0.09 \\
\hline $\mathrm{H} 2 \mathrm{O}^{+}$ & 1.37 & 1.48 & 0.68 & 0.34 \\
\hline $\mathrm{Cl}$ & 0.04 & 0.04 & 0.06 & 0.10 \\
\hline $\mathrm{F}$ & 0.10 & 0.14 & 0.10 & 0.15 \\
\hline Total & 100.75 & 100.45 & 99.50 & 99.91 \\
\hline \multicolumn{5}{|c|}{ Elements, ppm } \\
\hline $\mathrm{Li}$ & 11 & 19 & 10 & 16 \\
\hline $\mathrm{Rb}$ & 18 & 26 & 52 & 138 \\
\hline $\mathrm{Ba}$ & 482 & 628 & 963 & 250 \\
\hline $\mathrm{Sr}$ & 863 & 1372 & 1620 & 70 \\
\hline $\mathrm{Cr}$ & 68 & 34 & 26 & 24 \\
\hline $\mathrm{Ni}$ & 75 & 32 & 12 & 10 \\
\hline $\mathrm{V}$ & 315 & 192 & 33 & 13 \\
\hline Co & 63 & 40 & 7 & 2 \\
\hline $\mathrm{Zr}$ & 120 & 180 & 569 & 420 \\
\hline $\mathrm{Nb}$ & 20 & 68 & 147 & 2690 \\
\hline $\mathrm{La}$ & 6.5 & 15.5 & 65 & 223 \\
\hline $\mathrm{Ce}$ & 56 & 80 & 95 & 163 \\
\hline $\mathrm{Nd}$ & 22 & 42 & 48 & 54 \\
\hline $\mathrm{Sm}$ & 5.2 & 10 & 9 & 6 \\
\hline $\mathrm{Eu}$ & 2 & 2.2 & 1.9 & 1 \\
\hline $\mathrm{Gd}$ & 1 & 2 & 3.5 & 5.6 \\
\hline $\mathrm{Y}$ & 28 & 32 & 27 & 55 \\
\hline $\mathrm{Yb}$ & 3.4 & 3.3 & 3.0 & 4 \\
\hline $\mathrm{Tb}$ & 0.5 & 1 & 1.5 & 3 \\
\hline $\mathrm{Lu}$ & - & 0.3 & 0.5 & 0.8 \\
\hline Hf & 7 & 9.9 & 6.8 & 30 \\
\hline
\end{tabular}

$\mathrm{n}$ - number of samples.

and 6) the points form a single trend with those of the Tommot complex, while on Batchelor and Bowden (1985) (Fig. 9) and Thornton and Tuttle (1960) diagrams (Fig. 10) they fall into the field of anorogenic crustal granites. On a L. S. Borodin diagram of petrochemical series the points deviate to the latite and high-potassium late-orogenic trends

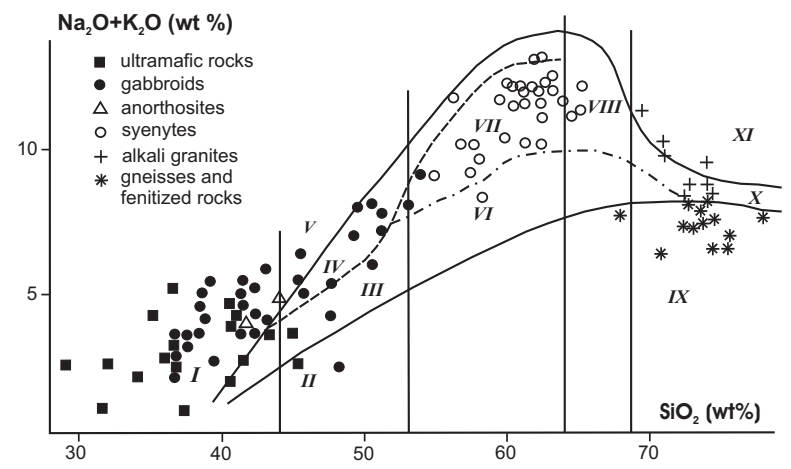

Fig. 5. Classification diagram for rocks from the Tommot and Somnitel'nyy plutons. Diagram fields (from Bogatikov et al., 1981): I - alkali-ultrabasites, II - gabbroids, III - subalkaline gabbroids, IV-V - alkaline gabbroids, VI - monzonites and syenites, VII alkali-syenites, VIII - alkaline quartz syenites, IX - granites, $\mathrm{X}$ alkali-granites, XI - pantellerites.

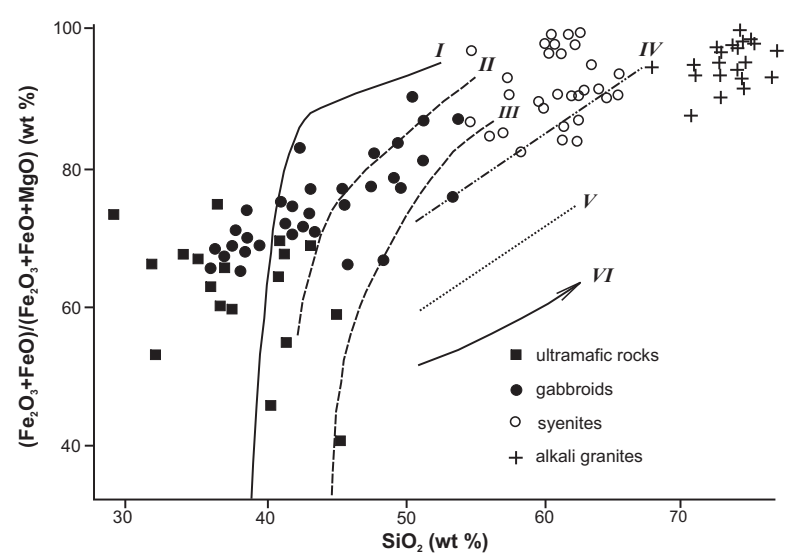

Fig. 6. Ratios of the fractionation index and $\mathrm{SiO}_{2}$ in magmatic rocks from the Tommot and Somnitel'nyy plutons. Trends of the petrochemical series (from Kononova, 1984): I - alkali-ultrabasites, II, III, IV - K-Na-alkaline basites, V - K-alkaline basites, VI - calcalkaline rocks.

(Borodin, 1987). High initial ${ }^{87} \mathrm{Sr} /{ }^{86} \mathrm{Sr}$ isotope ratio (0.7441) and a deep Eu-minimum on the REE distribution trend (Fig. 11) also indicate a substantially crustal nature of the parental magma.

\section{Geochronology and isotope geochemistry}

K-Ar ages for the Tommot and Somnitel'nyy plutons presented by Proshchenko and Nenashev (1969) were recalculated using the constants of Steiger and Jaeger (1977) (Table 2). New K-Ar, Rb-Sr (Tables 3 and 4, Fig. 12), and ${ }^{40} \mathrm{Ar} /{ }^{39} \mathrm{Ar}$ age (Table 5, Fig. 13) determinations were made as well. Details of the ${ }^{40} \mathrm{Ar} /{ }^{39} \mathrm{Ar}$ analyses are given in Supplement, see http://www.stephan-mueller-spec-publ-ser.net/ 4/97/2009/smsps-4-97-2009-supplement.pdf. 


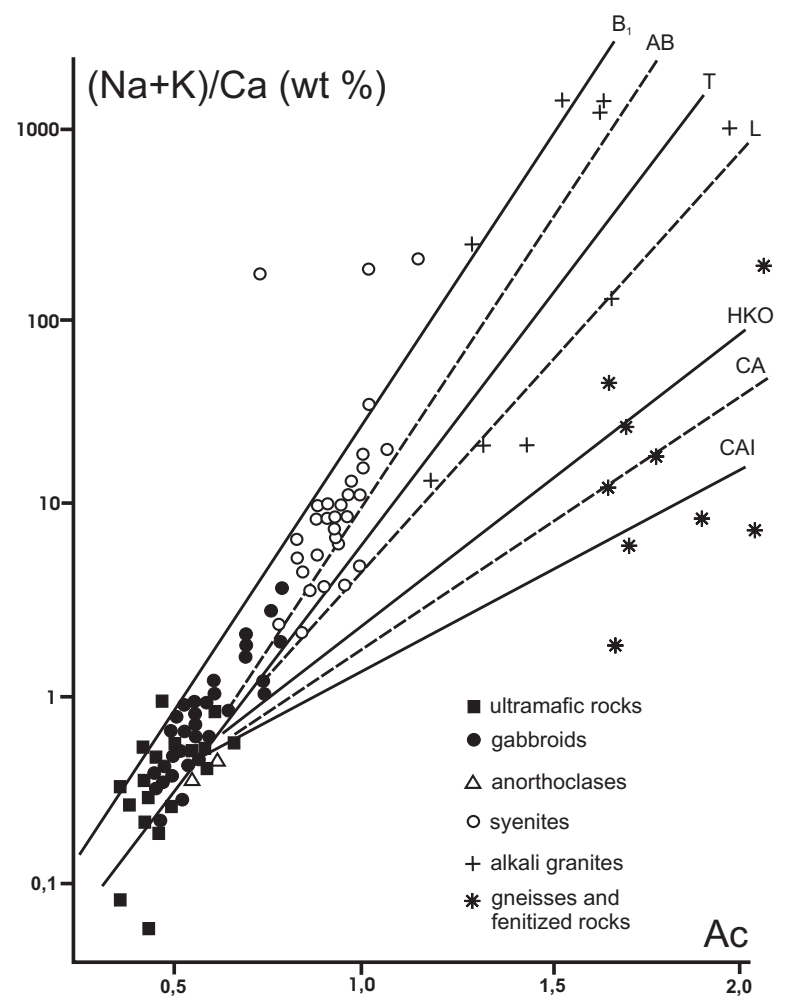

Fig. 7. Petrochemical series diagram for the rocks from the Tommot and Somnitel'nyy plutons. Main trends of magmatic evolution (from Borodin, 1987): CAI - low alkaline, CA - main calc-alkaline, $\mathrm{HKO}$ - high potassic late orogenic, $\mathrm{L}$ - latite, $\mathrm{T}$ - trachyte, $\mathrm{AB}-$ alkaline basalt, $\mathrm{B} 1-$ basanite. $\mathrm{Ac}=4 \mathrm{Si}$ [cation content] $/ \mathrm{X}$, where $\mathrm{X}=$ total activities of all main elements without $\mathrm{Si}$ of the rock analysis, using the following Goldschmidt ion potentials: $\mathrm{Si}=1$; $\mathrm{Ti}=1.5$; $\mathrm{Fe} 3+=2 ; \mathrm{Fe} 20, \mathrm{Mn}=5 ; \mathrm{Mg}=5.5 ; \mathrm{Ca}=7.5 ; \mathrm{Li}=8 ; \mathrm{Na}=8.5 ; \mathrm{K}, \mathrm{Rb}=9.5$; $\mathrm{Cs}=10$.

Alkaline-ultramafic rocks of the Tommot pluton (whole rock and pyroxenes) have been dated at 367-398 Ma by the $\mathrm{K}$-Ar method (Table 2). Hornblende from pyroxenite has a poorly defined ${ }^{40} \mathrm{Ar} /{ }^{39} \mathrm{Ar}$ plateau with a weighted mean age of $346 \pm 4 \mathrm{Ma}$ (Sample TM-4; Table 5, Fig. 13). Rb$\mathrm{Sr}$ analysis on whole rock and mineral separates did not yield sufficient isotopic variability for us to construct an isochron for these rocks. Model initial ${ }^{87} \mathrm{Sr} /{ }^{86} \mathrm{Sr}$ (assuming an age of $346 \mathrm{Ma}$ ) for most rocks and minerals are low $\left({ }^{87} \mathrm{Sr} /{ }^{86} \mathrm{Sr}_{i}=0.7024-0.7028\right)$ implying that depleted mantle was the source of alkaline-ultramafic melts (Table 4). Sr isotopic nonequilibrium in minerals (magnetite from jacupirangite shows ${ }^{87} \mathrm{Sr}^{86} \mathrm{Sr}_{i}=0.7047$ ) indicates the influence of late melts or fluids on the rocks.

Alkaline gabbros were dated at $327 \pm 28 \mathrm{Ma}$ by the $\mathrm{Rb}-\mathrm{Sr}$ method (Sample B-3/7; Table 3, Fig. 12). Rocks and minerals of the gabbroids are characterized by widely ranging initial values (0.7027-0.7050; Table 4$)$, which indicates their $\mathrm{Sr}$ isotopic nonequilibrium both in separate samples and on
Table 2. K-Ar ages of Tommot and Somnitelnyy igneous rocks.

\begin{tabular}{ll}
\hline Rock type & Age (Ma) \\
\hline jacupirangite & 398 \\
peridotite & 367 \\
gabbro & 330 \\
hornblendite & 329 \\
syenite & 248 \\
syenite & 228 \\
alkali-granite & 218 \\
granosyenite & 201 \\
granosyenite & 157 \\
microcline from pegmatite & 186 \\
microcline from pegmatite & 151 \\
microcline from pegmatite & 136 \\
\hline
\end{tabular}

Data from the paper of Proshchenko and Nenashev (1969) recalculated using the constants of Steiger and Jaeger (1977).

a larger scale. Even the minimum initial values of gabbroids (0.7026-0.7034), and plagioclases (0.7033-0.7048) are, on the average, higher than those of ultramafic rocks of the pluton. Sr isotopic heterogeneity of these rocks and minerals and their relatively high proportion of radiogenic $\mathrm{Sr}$ might be due to polygenetic nature of $\mathrm{Sr}$ (depleted mantle along with lower crustal fluids rich in $\mathrm{Rb}$ and radiogenic $\mathrm{Sr}$ and lithophile elements). Alkalization of the mafic melt probably occurred in the course of its evolution. The alkaline gabbro (Sample TM-1) is dated at $303 \pm 7 \mathrm{Ma}$ by the ${ }^{40} \mathrm{Ar} /{ }^{39} \mathrm{Ar}$ method.

An isochron $\mathrm{Rb}-\mathrm{Sr}$ age of alkali-syenite (tonsbergite) from sample B-3/6 of the main syenite body in the western contact zone of the gabbroid pluton (Fig. 2) was determined from whole rock, amphibole, K-feldspar and is $280 \pm 30 \mathrm{Ma}$ (Table 3$)$. The alkali-syenite is marked by a relatively high initial value (0.7040). A bioitite from this sample is discordant, and has a model age of $190 \mathrm{Ma}\left({ }^{87} \mathrm{Sr}^{86} \mathrm{Sr}_{i}=0.7047\right)$ and reflects post-magmatic nature of the mica or resetting of the isotopic system. According to ${ }^{40} \mathrm{Ar} /{ }^{39} \mathrm{Ar}$ dating, the age of syenites (Samples TM-5 and 75-5) is close to that of gabbro, i.e. about $300 \mathrm{Ma}$. The $\mathrm{Rb}-\mathrm{Sr}$ age of quartz-syenite from a small dike in the eastern edge of the gabbroid pluton was also derived from the mineral isochron (whole rock, amphibole, K-feldspar) and is $206 \pm 18 \mathrm{Ma}$ with still higher initial ${ }^{87} \mathrm{Sr} /{ }^{86} \mathrm{Sr}$ value $(0.7054 \pm 0.0011)$ which probably indicates the on-going influx of radiogenic $\mathrm{Sr}$ or/and the movement of the melting chamber into higher horizons. Intermediate ages of quartz syenites ( 248 and $228 \mathrm{Ma}$ ) were determined by the K-Ar method.

Alkali-granites of the Somnitel'nyy pluton were dated at 136-215 Ma (Table 2) by the K-Ar method. Rb-Sr mineral isochron from sample P-2313/1 has an age of $166 \pm 6 \mathrm{Ma}$ with an initial ${ }^{87} \mathrm{Sr} /{ }^{86} \mathrm{Sr}$ isotopic ratio of $0.744 \pm 0.008$. A high initial ${ }^{87} \mathrm{Sr} /{ }^{86} \mathrm{Sr}$ value indicates the crustal nature of 
Table 3. Rb-Sr isotopic ages of the Tommot and Somnitel'nyy plutons.

\begin{tabular}{|c|c|c|c|c|}
\hline Mineral & ${ }^{87} \mathrm{Rb}$ microg/g & ${ }^{86} \mathrm{Sr}$ microg/g & ${ }^{87} \mathrm{Rb} /{ }^{86} \mathrm{Sr}$ & ${ }^{87} \mathrm{Sr} /{ }^{86} \mathrm{Sr}$ \\
\hline \multicolumn{5}{|c|}{ B-3/7 essexite } \\
\hline whole rock & 27.6345 & 33.7273 & 0.8099 & 0.7087 \\
\hline amphibole & 5.3077 & 11.6671 & 0.4497 & 0.7071 \\
\hline K-feldspar & 29.8926 & 17.8402 & 1.6563 & 0.7127 \\
\hline \multicolumn{5}{|c|}{ Isochron: $327 \pm 28 \mathrm{Ma},{ }^{87} \mathrm{Sr} /{ }^{86} \mathrm{Sr}_{i}=0.7050 \pm 0.004, \mathrm{MSWD}=0.03$} \\
\hline \multicolumn{5}{|c|}{ B-3/6 alkali syenite (tonsbergite) } \\
\hline whole rock & 26.7850 & 20.4218 & 1.2965 & 0.7091 \\
\hline amphibole & 7.8785 & 26.2604 & 0.2966 & 0.7049 \\
\hline K-feldspar & 27.1557 & 75.9638 & 0.3534 & 0.7056 \\
\hline \multicolumn{5}{|c|}{ Isochron: $280 \pm 30 \mathrm{Ma},{ }^{87} \mathrm{Sr} /{ }^{86} \mathrm{Sr}_{i}=0.7040 \pm 0.0003, \mathrm{MSWD}=0.9$} \\
\hline biotite & 82.8135 & 7.8480 & 10.4308 & 0.7329 \\
\hline \multicolumn{5}{|c|}{ Errorchron with biotite: $190 \pm 14 \mathrm{Ma},{ }^{87} \mathrm{Sr} /{ }^{86} \mathrm{Sr}=0.7047 \pm 0.0010, \mathrm{MSWD}=4.6$} \\
\hline \multicolumn{5}{|c|}{ O-19/1 quartz syenite } \\
\hline whole rock & 11.8223 & 139.9760 & 0.0835 & 0.7058 \\
\hline amphibole & 3.2608 & 32.9203 & 0.0979 & 0.7055 \\
\hline K-feldspar & 24.8808 & 14.1192 & 1.7419 & 0.7105 \\
\hline \multicolumn{5}{|c|}{ Isochron: $206 \pm 18 \mathrm{Ma},{ }^{87} \mathrm{Sr} /{ }^{86} \mathrm{Sr}_{i}=0.7054 \pm 0.0003, \mathrm{MSWD}=0.5$} \\
\hline \multicolumn{5}{|c|}{ P-2313/1 alkali-granite } \\
\hline whole rock & 6.0387 & 0.9193 & 81.7625 & 0.9397 \\
\hline aegirine & 7.4552 & 1.1105 & 6.6362 & 0.7554 \\
\hline K-feldspar & 186.0500 & 1.0475 & 175.5708 & 1.1359 \\
\hline \multicolumn{5}{|c|}{ Isochron: $166 \pm 6 \mathrm{Ma},{ }^{87} \mathrm{Sr} /{ }^{86} \mathrm{Sr}_{i}=0.744 \pm 0.008, \mathrm{MSWD}=1.6$} \\
\hline
\end{tabular}

For samples B-3/7, B-3/6 and O- $19 / 1$ errors on ${ }^{87} \mathrm{Rb} /{ }^{86} \mathrm{Sr}=0.1 \%,{ }^{87} \mathrm{Sr} /{ }^{86} \mathrm{Sr}=0.05 \%$. For sample $\mathrm{P}-2312 / 1$ errors on ${ }^{87} \mathrm{Rb} /{ }^{86} \mathrm{Sr}=1 \%$, ${ }^{87} \mathrm{Sr} /{ }^{86} \mathrm{Sr}=1 \%$. Isochrons calculated and plotted (Fig. 13) using software by Ludwig (2003).

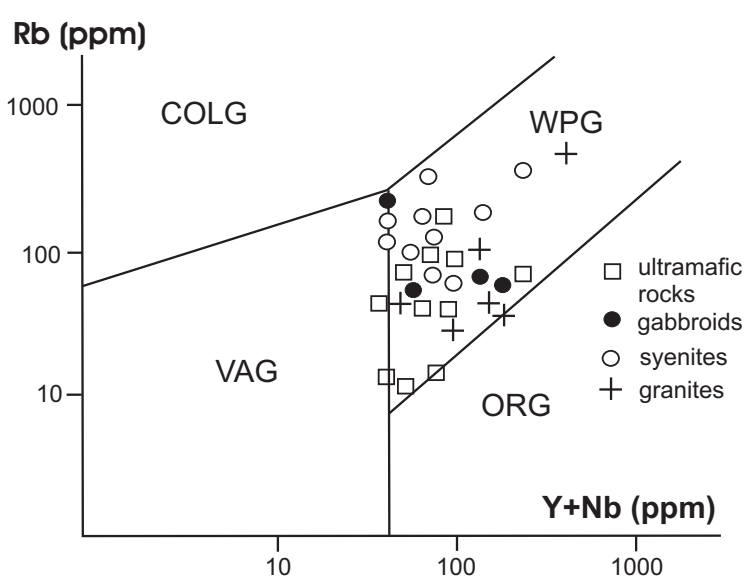

Fig. 8. Geochemical diagram for the rocks from the Tommot and Somnitel'nyy plutons. Diagram fields (from Pearce, 1982): ORG - ocean ridge granites, VAG - volcanic arc granite, WPG - within plate granite, COLG - collision granite.

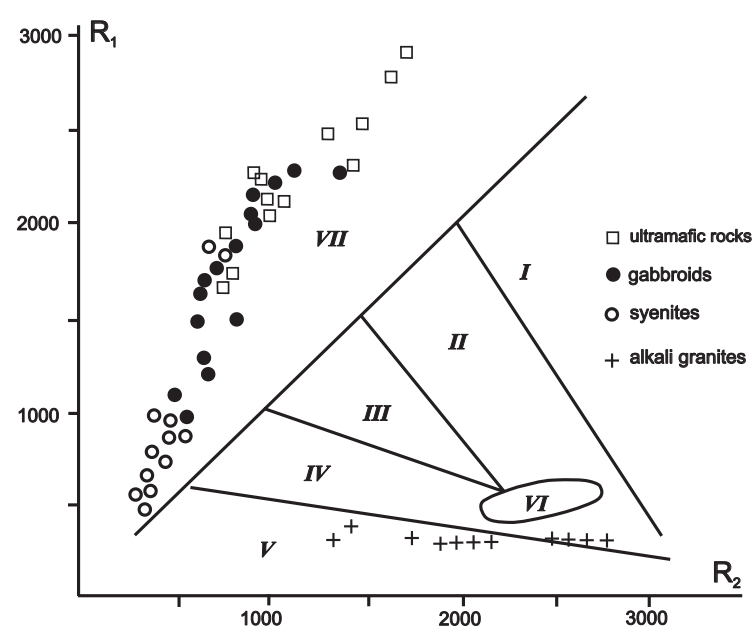

Fig. 9. Main petrogenic oxide ratios for the rocks from the Tommot and Somnitel'nyy plutons. Diagram fields (from Batchelor and Bowden, 1985): I - fractional crystallization of mantle melt, II pre-collisional, III - post-collisional uplift, IV - late-orogenic, V anorogenic, VI - syn-collisional, VII - fractional crystallization of alkaline-basalt melts. $R_{1}=4 \mathrm{Si}+11(\mathrm{Na}+\mathrm{K})+2(\mathrm{Fe}-\mathrm{Ti}) ; R_{2}=6 \mathrm{Ca}+2$ MgvAl. 
Table 4. Rb-Sr isotopic data from the Tommot and Somnitelnyy plutons.

\begin{tabular}{|c|c|c|c|c|c|c|}
\hline $\begin{array}{l}\text { Sample } \\
\text { number }\end{array}$ & $\begin{array}{l}\text { Rock or } \\
\text { mineral }\end{array}$ & $\begin{array}{l}{ }^{87} \mathrm{Rb} \\
\text { microg/g }\end{array}$ & $\begin{array}{l}{ }^{86} \mathrm{Sr} \\
\text { microg/g }\end{array}$ & ${ }^{87} \mathrm{Rb} /{ }^{86} \mathrm{Sr}$ & ${ }^{87} \mathrm{Sr} /{ }^{86} \mathrm{Sr}$ & $\begin{array}{l}{ }^{*} \text { Modeled } \\
{ }^{87} \mathrm{Sr} /{ }^{86} \mathrm{Sr}_{i}\end{array}$ \\
\hline \multicolumn{7}{|c|}{ Gabbroids modeled with age $=346 \mathrm{Ma}$} \\
\hline B-22/4 & $\begin{array}{l}\text { jacupirangite } \\
\text { pyroxene } \\
\text { magnetite }\end{array}$ & $\begin{array}{l}1.3860 \\
0.8081 \\
1.6128\end{array}$ & $\begin{array}{l}12.7407 \\
7.6450 \\
29.6944\end{array}$ & $\begin{array}{l}0.1075 \\
0.1045 \\
0.0537\end{array}$ & $\begin{array}{l}0.7029 \\
0.7033 \\
0.7050\end{array}$ & $\begin{array}{l}0.7024 \\
0.7028 \\
0.7047\end{array}$ \\
\hline B- $9 / 4$ & $\begin{array}{l}\text { peridotite } \\
\text { pyroxene }\end{array}$ & $\begin{array}{l}2.8865 \\
1.1773\end{array}$ & $\begin{array}{l}32.9150 \\
5.8527\end{array}$ & $\begin{array}{l}0.0867 \\
0.1988\end{array}$ & $\begin{array}{l}0.7031 \\
0.7037\end{array}$ & $\begin{array}{l}0.7027 \\
0.7027\end{array}$ \\
\hline B-24/3 & $\begin{array}{l}\text { theralite } \\
\text { pyroxene } \\
\text { amphibole } \\
\text { plagioclase }\end{array}$ & $\begin{array}{l}7.8538 \\
1.0408 \\
1.2148 \\
10.0546\end{array}$ & $\begin{array}{l}145.3900 \\
53.2449 \\
74.6086 \\
147.1030\end{array}$ & $\begin{array}{l}0.0534 \\
0.0193 \\
0.0161 \\
0.0676\end{array}$ & $\begin{array}{l}0.7038 \\
0.7032 \\
0.7030 \\
0.7035\end{array}$ & $\begin{array}{l}0.7036 \\
0.7031 \\
0.7029 \\
0.7032\end{array}$ \\
\hline B-26/3 & $\begin{array}{l}\text { bytownitite } \\
\text { plagioclase }\end{array}$ & $\begin{array}{l}11.8934 \\
13.2041\end{array}$ & $\begin{array}{l}150.2160 \\
150.1780\end{array}$ & $\begin{array}{l}0.0783 \\
0.0869\end{array}$ & $\begin{array}{l}0.7037 \\
0.7040\end{array}$ & $\begin{array}{l}0.7033 \\
0.7036\end{array}$ \\
\hline B- $9 / 3$ & $\begin{array}{l}\text { hornblendite } \\
\text { amphibole }\end{array}$ & $\begin{array}{l}1.8707 \\
2.2343\end{array}$ & $\begin{array}{l}62.6792 \\
75.9660\end{array}$ & $\begin{array}{l}0.0295 \\
0.0291\end{array}$ & $\begin{array}{l}0.7034 \\
0.7035\end{array}$ & $\begin{array}{l}0.7033 \\
0.7034\end{array}$ \\
\hline B-15/6 & $\begin{array}{l}\text { hornblendite } \\
\text { amphibole }\end{array}$ & $\begin{array}{l}1.6841 \\
1.8931\end{array}$ & $\begin{array}{l}103.5470 \\
82.9492\end{array}$ & $\begin{array}{l}0.0161 \\
0.0226\end{array}$ & $\begin{array}{l}0.7029 \\
0.7028\end{array}$ & $\begin{array}{l}0.7027 \\
0.7026\end{array}$ \\
\hline \multicolumn{7}{|c|}{ Syenite modeled with age $=200 \mathrm{Ma}$} \\
\hline B-2306/9 & $\begin{array}{l}\text { quartz syenite } \\
\text { plagioclase } \\
\text { amphibole } \\
\text { biotite }\end{array}$ & $\begin{array}{l}5.9160 \\
6.1522 \\
3.1400 \\
9.6058\end{array}$ & $\begin{array}{l}164.2280 \\
289.4710 \\
162.9480 \\
116.5240\end{array}$ & $\begin{array}{l}0.0356 \\
0.0210 \\
0.0190 \\
0.0815\end{array}$ & $\begin{array}{l}0.7047 \\
0.7035 \\
0.7049 \\
0.7051\end{array}$ & $\begin{array}{l}0.7046 \\
0.7034 \\
0.7048 \\
0.7049\end{array}$ \\
\hline
\end{tabular}

${ }^{*}{ }^{87} \mathrm{Sr} /{ }^{86} \mathrm{Sr}_{i}$ : initial $\mathrm{Sr}$ isotope composition corrected for the age of $346 \mathrm{Ma}$ for all samples except B-2306/9 for which $200 \mathrm{Ma}$ was used.

Table 5. Summary of argon analyses.

\begin{tabular}{|c|c|c|c|c|c|}
\hline Sample & Rock type & Mineral & Integrated age (Ma) & Weighted mean age (Ma) & Information \\
\hline TM-4 & pyroxenite & hornblende & $391.8 \pm 0.7$ & $346 \pm 4(W)$ & $\begin{array}{l}3 \text { fractions } \\
96 \%{ }^{39} \mathrm{Ar} \text { release } \\
\mathrm{MSWD}=43\end{array}$ \\
\hline TM-1 & $\begin{array}{l}\text { cumulate } \\
\text { gabbro }\end{array}$ & hornblende & $312.8 \pm 0.5$ & $303 \pm 7(W)$ & $\begin{array}{l}9 \text { fractions } \\
97 \%{ }^{39} \mathrm{Ar} \text { release } \\
\text { MSWD }=199\end{array}$ \\
\hline TM-5 & syenite & hornblende & $306.5 \pm 0.5$ & $303 \pm 6(W)$ & $\begin{array}{l}4 \text { fractions } \\
75 \%{ }^{39} \text { Ar release } \\
\text { MSWD }=191\end{array}$ \\
\hline $75-5$ & syenite & hornblende & $306.5 \pm 1.4$ & $299 \pm 4(W)$ & $\begin{array}{l}3 \text { fractions } \\
48 \%{ }^{39} \mathrm{Ar} \text { release } \\
\mathrm{MSWD}=11\end{array}$ \\
\hline $75-5$ & syenite & biotite & $293.3 \pm 1.3$ & $298 \pm 20(W)$ & $\begin{array}{l}9 \text { fractions } \\
91 \%{ }^{39} \text { Ar release } \\
\text { MSWD }=215\end{array}$ \\
\hline $1090-3$ & granite & biotite & $139.5 \pm 0.7$ & $141 \pm 2(W)$ & $\begin{array}{l}6 \text { fractions } \\
11 \text { fractions } \\
95 \%{ }^{39} \mathrm{Ar} \text { release } \\
\text { MSWD }=13\end{array}$ \\
\hline
\end{tabular}

Weighted mean age is the weighed (by ${ }^{39}$ Ar release) average of fractions that form a poorly-defined plateau. MSWD: Mean square weighted deviates. 


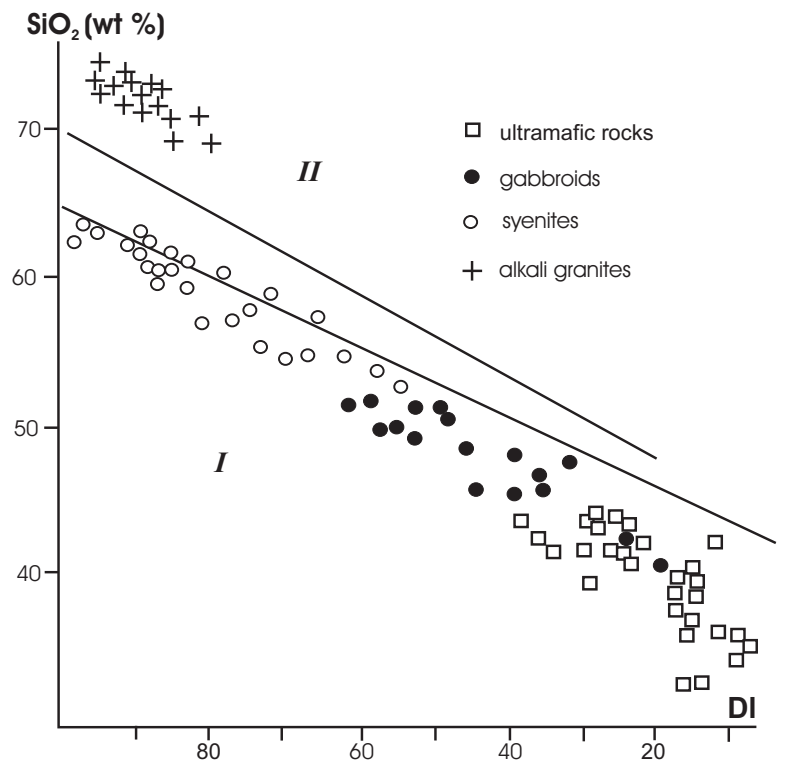

Fig. 10. Ratios of the differentiation index and $\mathrm{SiO}_{2}$ from the rocks of the Tommot and Somnitel'nyy plutons. Diagram fields (from Thornton and Tuttle, 1960): I - differentiation of mantle magmas, II - differentiation of crustal granitoid magmas.

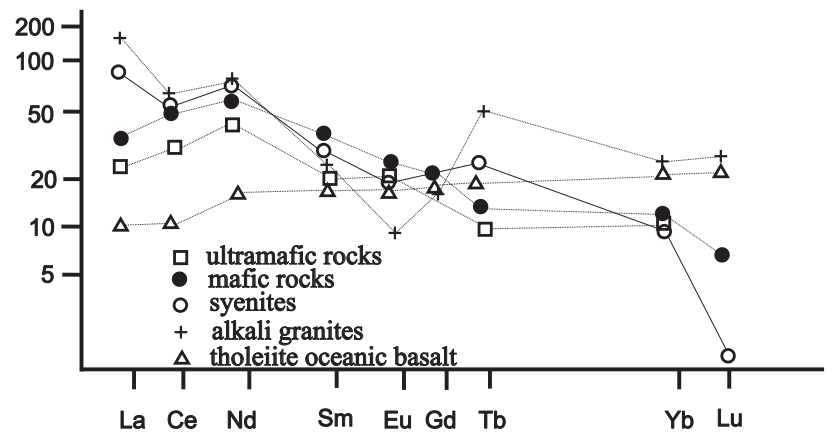

Fig. 11. Chondrite-normalized rare earth element (REE) distribution pattern for the rocks of the Tommot and Somnitel'nyy plutons. Chondrite normalization values are from Balashov (1976). REE concentrations in oceanic basalts are from Kuz'min (1985).

the granite-forming substratum. ${ }^{40} \mathrm{Ar} /{ }^{39} \mathrm{Ar}$ dating of bioite (Sample 1090-3) from one of the smaller granite phases has an age of $141 \pm 2 \mathrm{Ma}$, similar to ages from other granites in the region (Layer et al., 2001) which we interpret to reflect cooling through the closure temperature of biotite. A basalt (Sample 1079/11) that shows significant excess argon and a ${ }^{40} \mathrm{Ar} /{ }^{39} \mathrm{Ar}$ errochron age of $190 \mathrm{Ma}$, probably a reset or partial reset age.
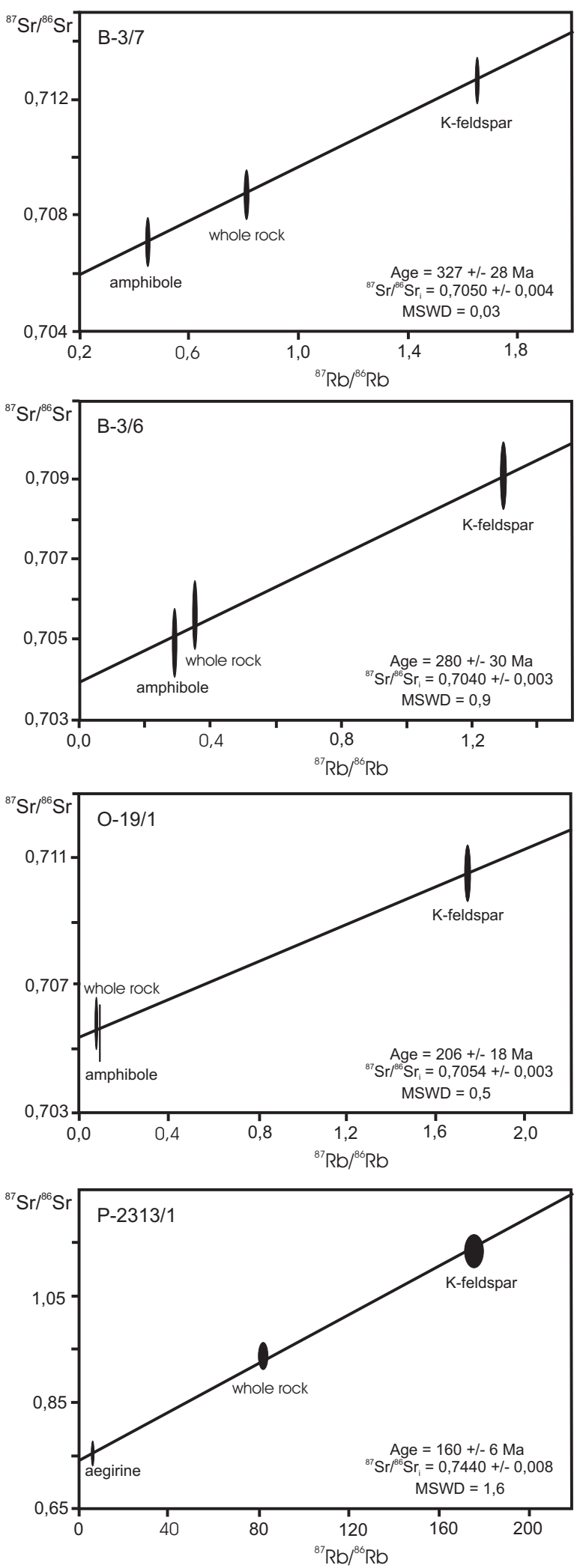

Fig. 12. Rb-Sr isochron plots for rocks from the Tommot and Somnitel'nyy plutons. 

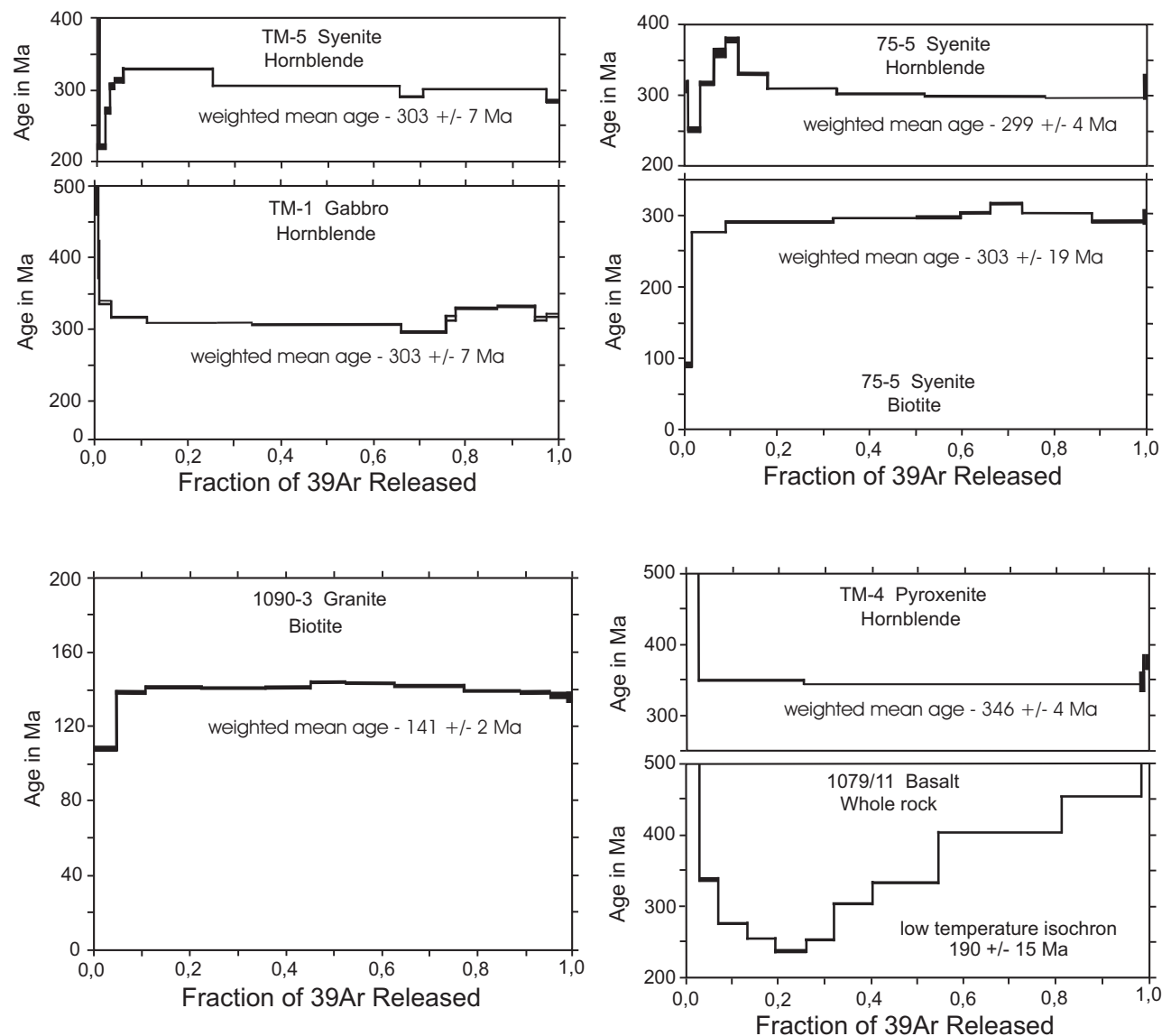

Fig. 13. ${ }^{40} \mathrm{Ar} /{ }^{39} \mathrm{Ar}$ age spectra from rocks of the Tommot plutons. Interpreted ages from Table 5 are shown.

\section{Discussion}

The problem of genesis of alkaline magmas remains to be open to discussion. Alternative hypotheses include: fractionation of primary alkaline, basaltoid and peridotitic magmas (Yoder and Tilley, 1962) and the influence of melts or fluids rich in alkali on mafic substrata (Kuznetsov, 1964; Kuz'min, 1985). The formation of alkali-syenites and granites is often related to the processes of assimilation of carbonate rocks (Barker and Long, 1969) and metasomatic fenitization (Kononova, 1984). The results of the conducted investigations imply that alkaline-ultramafic and alkaline-syenitoid rocks formed as derivatives of alkalized magma through interaction with upper mantle melts.

The available geochronological data confirm, in general, the field observations of the sequence of formation of various rocks of the Tommot and Somnitel'nyy plutons: alkalineultramafic rocks which are older than alkali gabbro which are older than alkali syenites which are older than alkaligranites with large gaps in time. Although previous studies have suggested a long (inordinate) formation history of alkaline complexes, for example, alkaline complexes of the African rift formed for as long as $1400 \mathrm{Ma}$ (Sorensen, 1974), the Monterigian Province in Canada for $900 \mathrm{Ma}$ (Philpots, 1974) and the alkaline province in southwest Greenland for $400 \mathrm{Ma}$ (Upton, 1974), we believe that the rock types and geochronology preserved at the Tommot pluton reflects three discrete events and not a single protracted evolutionary history.

The first event, marked by the mafic and ultramafic rocks reflects Devonian rifting along the eastern margin of Siberia (Nokleberg et al., 2005). The second event (syenites) reflects a period of Late Carboniferous extension (Nokleberg et al., 2005). While the third reflects plutonism synchronous with subduction and collision of the Kolyma-Omolon superterrane with the eastern margin of the Siberian Craton (Layer et al., 2001).

\section{Conclusions}

1. The Tommot pluton is located within the inner zone of the Verkhoyansk-Kolyma Mesozoides. This is a polychronous formation made of alkaline ultrabasites, alkaline and subalkaline gabbroids, and alkaline and quartz syenites that was the locus of discrete magmatic events 
from the Late Devonian to the Late Jurassic/Early Cretaceous.

2. Pyroxenites preserve Late Devonian to Early Carboniferous ages that reflect the time of Middle Paleozoic rifting of the eastern Siberia continental margin (Nokleberg et al., 2005).

3. Late Carboniferous syenites and gabbros formed during a period of crustal extension within the Omulevka terrane (Nokleberg et al., 2005).

4. Granitic plutonism of the Somnitel'nyy pluton is synchronous with collision of the Kolyma-Omolon Superterrane to Siberia (Layer et al., 2001).

5. Magma-forming substrata for the melts that produced the Tommot pluton rocks were upper depleted horizons of the mantle. In the course of the magmatic chamber evolution the melts underwent alkalization at depth, most probably under the influence of fluids rich in lithophile, light rare-earth elements, rubidium, and strontium.

Acknowledgements. We thank Andrei V. Prokopiev for the useful discussion of the paper, Yurii K. Bredyuk and V. Oxman for the rock samples he presented to us for ${ }^{40} \mathrm{Ar} /{ }^{39} \mathrm{Ar}$ dating and heads of the Yakutian State Geological Expedition and the "Lenskoye" State Geological Enterprise for the help in organizing field work. This research is a part of a cooperative research program between the Yakutian Institute of Geological Sciences, The University of Alaska at Fairbanks, and the Michigan State University and was supported by NSF grant OPP-9224193, Russian Science Foundation (grant 06-05-96008), International Science Foundation (grant RO 2000), and the Siberian Branch of Russian Academy of Sciences. We are thankful to David Stone, Jaime Toro and Warren Nokleberg for their constructive comments which helped in preparing the paper.

\section{References}

Andreeva, E. D., Kononova, V. A., and Sveshnikova, E. V.: Typomorphism of the alkaline rock minerals as a mineralogical index of alkaline series. Magmatic rocks. Alkaline rocks, Nauka, Moscow, 281-305, 1984 (in Russian).

Balashov, Yu. A.: Geochemistry of the REE, Nauka, Moscow, 192 pp. 1976 (in Russian).

Barker, D. S. and Long, L. E.: Feldspatoidal syenite in a quartz diabase sill, Breokville, New Jersey, J. Petrol., 10, 202-221, 1969.

Batchelor, R. A. and Bowden, P.: Petrographic interpretation of granitoid rock series using multicationic parameters, Chem. Geol., 48, 43-55, 1985.

Borodin, L. S.: Petrochemistry of magmatic series. Nauka, Moscow, 241 pp., 1987 (in Russian).

Brown, G. G. and Parsons, J.: Calorimetric and phase-diagram approaches to two-feldspar geothermometry: a critique, Am. Mineral., 70(3-4), 356-361, 1985.

Bushlyakov, I. N. and Kholodnov, V. V.: Halogens in the petrogenesis of granitoids, Nauka, Moscow, 192 pp., 1986 (in Russian).
Bogatikov, O. A., Mikhailov, N. P., and Gon'shakova, V. I. (Eds.): Classification and nomenclature of the magmatic rock, Nedra, Moscow, 159 pp., 1981, (in Russian).

Dorofeev, A. V.: Geologic map of the USSR at 1:200 000 scale. Sheets R-54-XXVII, XXVIII, Aerogeology, Nedra, Moscow, 62 pp., 1967 (in Russian).

Entin, A. R., Biryukov, V. M., and Zaitsev, A. I.: On the age of ultrabasic-alkaline rocks and carbonatites of the Gornoozerskiy and Povorotnyy massifs (Sette-Daban, Yakutia), Geol. Geofiz., 7, 57-66, 1991 (in Russian).

Entin, A. R., Zaitsev, A. I., and Nenashev, N. I.: On the sequence of geologic events related to the emplacement of the Tomtor massif ultrabasic-alkaline rocks and carbonatites. Geol. Geofiz., 12, 4251, 1990 (in Russian).

Kovalenko, V. I.: Petrology and geochemistry of the rare-metal granitoids. Nauka, Novosibirsk, 173 pp., 1977 (in Russian).

Kononova, V. A. (Ed.): Causes of diversity and problems in the genesis of alkaline, in: Magmatic rocks, Alkaline rocks, Nauka, Moscow, 306-380, 1984, (in Russian).

Kuznetsov, Yu. A.: Main types of magmatic formations, Nauka, Moscow, 387 pp., 1964 (in Russian).

Kuz'min, M. I.: Geochemistry of magmatic rocks of Phanerozoic foldbelts, Nauka, Novosibirsk, 199 pp., 1985 (in Russian).

Layer, P. W., Newberry, R., Fujita, K., Parfenov, L., Trunilina, V., and Bakharev, A.: Tectonic setting of the plutonic belts of Yakutia, Northeast Russia, based on ${ }^{40} \mathrm{Ar} /{ }^{39} \mathrm{Ar}$ geochronology and trace element geochemistry, Geology, 29, 167-170, 2001.

Laz'ko, Ye. Ye.: Typomorphism of ultramafic rock-forming minerals, in: Ultrabasic rocks, edited by: Laz'ko, Ye. Ye., and Sharkov, Ye. V., Nauka, Moscow, 424-441, 1988, (in Russian).

Ludwig, K. R.: User's manual for Isoplot 3.00 A geochronological toolkit for Microsoft Excel, Berkeley Geochronology Center Special Publication 4, 70 pp., 2003.

Nekrasov, I. Ya.: Magmatism and ore-bearing capacity of northeastern Verkhoyansk-Chukotka folded area, Izd-vo AN SSSR, Moscow, 334 pp., 1962 (in Russian).

Neustroev, A. P., Parfenov, L. M., and Rodinov, V. P.: Paleomagnetic data and the nature of the Tas-Khayakhtakh terrane (Verkhoyansk region), Geol. Geofiz., 8, 25-37, 1993 (in Russian).

Nokleberg, W. J., Bundtzen, T. K., Eremin, R. A., Ratkin, V. V., Dawson, K. M., Shpikerman, V. I., Goryachev, N. A., Byalobzhesky, S. G., Frolov, Y. F., Khanchuk, A. I., Koch, R. D., Monger, J. W. H., Pozdeev, A.I., Rozenblum, I. S., Rodionov, S. M., Parfenov, L. M., Scotese, C. R., and Siderov, A. A.: Metallogenesis and tectonics of the Russian Far East, Alaska, and the Canadian Cordillera, US Geological Survey Professional paper, 1697, 397 pp., 2005.

Parfenov, L. M.: Continental margins and island arcs of the Mesozoides of northeast Asia, Nauka, Novosibirsk, 189 pp., 1984 (in Russian).

Parfenov, L. M.: Tectonics of the Verkhoyansk-Kolyma Mesozoides in the context of plate tectonics, Tectonophysics, 199, 319-342, 1991.

Parfenov, L. M.: Accretion history of northeast Asia, in: Proceedings of the First International Conference on Arctic Margins, edited by: Thurston, D. and Fujita, K., US Minerals Management Service, Anchorage, 83-188, 1994.

Pearce, J. A.: Trace element characteristics of lavas from destruc- 
tive plate boundaries, in: Andesites, R. S. Thorpe (Editor), Wiley, Chichester, 525-548, 1982.

Perchuk, L. L.: Equilibria of the rock-forming minerals, Nauka, Moscow, 387 pp., 1970 (in Russian).

Perchuk, L. L.: Pyroxene barometer and pyroxene geotherms, Dokl. Akad. Nauk SSSR+, 233(6), 1196-1199, 1977 (in Russian).

Philpots, A. R.: The Monterigian Province, in: The Alkaline Rocks, edited by: Sorensen, H., Wiley, London, 293-311, 1974.

Proshchenko, E. G. and Nenashev, N. I.: Geological interpretation of the radiogenic age of the rocks of the Tommot complex gabbro-syenite intrusion, Izv. AN SSSR Geol.+, 12, 26-32, 1969 (in Russian).

Sorensen, H. (Ed.): Origin of the alkaline rocks - a summary and retrospect, in: The Alkaline Rocks, Wiley, London, 535-542, 1974.

Steiger, R. H. and Jaeger, E.: Subcommission on geochronology: Convention on the use of decay constants in geo and cosmochronology, Earth Planet. Sc. Lett., 36, 359-362, 1977.
Stone, D. B.: Paleomagnetic Paleolatitudes for Northeast Russia: an Update, in: Origin of Northeast Russia: Paleomagnetism, Geology \& Tectonics, University of Alaska Geophysical Institute Report UAG-R-330 (CD and http://www.gi.alaska.edu/nerussia), 2006

Thornton, C. P. and Tuttle, O. F.: Chemistry of igneous rocks, differentiation index, Am. J. Sci., 258(11), 664-684, 1960.

Troshin, Yu. P. , Grebenschikova, V. T., and Antonov, A. Yu.: Volatile components in biotites and metallogenic specialization of intrusions. Mineralogical criteria for evaluation of the content, Nauka, Leningrad, 73-83, 1981 (in Russian).

Upton, B. G. J.: The alkaline province of southwest Greenland, in: The Alkaline Rocks, edited by: Sorensen, H., Wiley, London, 221-238, 1974.

Yoder, H. S. and Tilley, C. P.: Origin of basalt magmas, an experimental study of natural and synthetic rocks systems, J. Petrol., 3, 342-532, 1962.

Wones, D. R. and Eugster, H. P.: Stability of biotite: experiment, theory and application. Am. Mineral., 9, 1228-1272, 1965. 